УДК: 7.036

ББК: 85.103(5)6

A43

DOI: $10.18688 / \mathrm{aa} 188-4-41$

Hisashi Yakou

\title{
The Formation of Landscapes in the Sakhalin and Kuril Islands
}

The history of the Sakhalin Region under Soviet and modern Russian rule started with the defeat of the Japanese Empire in 1945. Until then, Sakhalin was considered culturally a part of Japan, as we can see in a memorial postcard of the thirtieth anniversary of Japanese administration in Sakhalin (Fig. 1). In the drawing by Kōjirō Funasaki (1900-1987), known only as an editor and illustrator of alpine plants books, the imperial Shinto shrine of Karafuto (old Japanese name of Sakhalin) is portrayed at the foot of mountains with the typical Torii gates to the sanctuary. The techniques are those of Japanese traditional painting, including the insertion of flowing haze or clouds to give a sense of distance and to show a general view from above.

A drastic change of scenery is symbolically depicted in a 1950 work by Pavel Pogodin (1916-1983) (Fig. 2). This nearly forgotten artist was a native of Nizhny Novgorod Oblast, but worked in Sakhalin and Brest, Belarus, which were at opposite edges of the Soviet territory [1, p. 244]. Wooden Japanese houses were replaced by a high-roofed building with a colonnade on the facade in the painting. This is symbolic of the Sovietization process of urban views. What happened, then, to the nature landscapes of the region? Geographical features cannot be easily altered, but I would like to argue that a similar change might be discerned on the level of representation. Representation-this paper discusses landscape paintings, but other genres of art such as literature, photography, etc., should be properly discussed somewhere else - is a way to see and show things in different perspectives and modifies the meanings of things. In the case of landscapes, representation could perform a political function, as we will see below. Here, political means the Russification of territory in the Sakhalin and Kuril Islands.

Boris Shakhnazarov (1905-1993) is considered the first Sakhalin artist, although he came from Georgia and lived in Khabarovsk after his fifteen-year stay in Sakhalin until 1961 [3, pp.28-36]. He chose fish and crabs as the motifs of still lifes, and seals, sea lions, and sea birds as those of coastal landscapes. Since then, the ocean and its related objects have been consistent themes in Sakhalin art.

Another artist from Georgia, Givi Mantkava (1930-2003), settled in Sakhalin in 1956 and expanded the field of painting, introducing characteristic subjects of the Socialist Realism such as the scenes of labor. Fishermen and female workers in fish processing factories were featured in a bright and optimistic atmosphere of a Socialist society [2]. Mantkava turned his curious eyes on indigenous people and, in his later years, the harsh realities the Russian community faced after the demise of Soviet Union. 


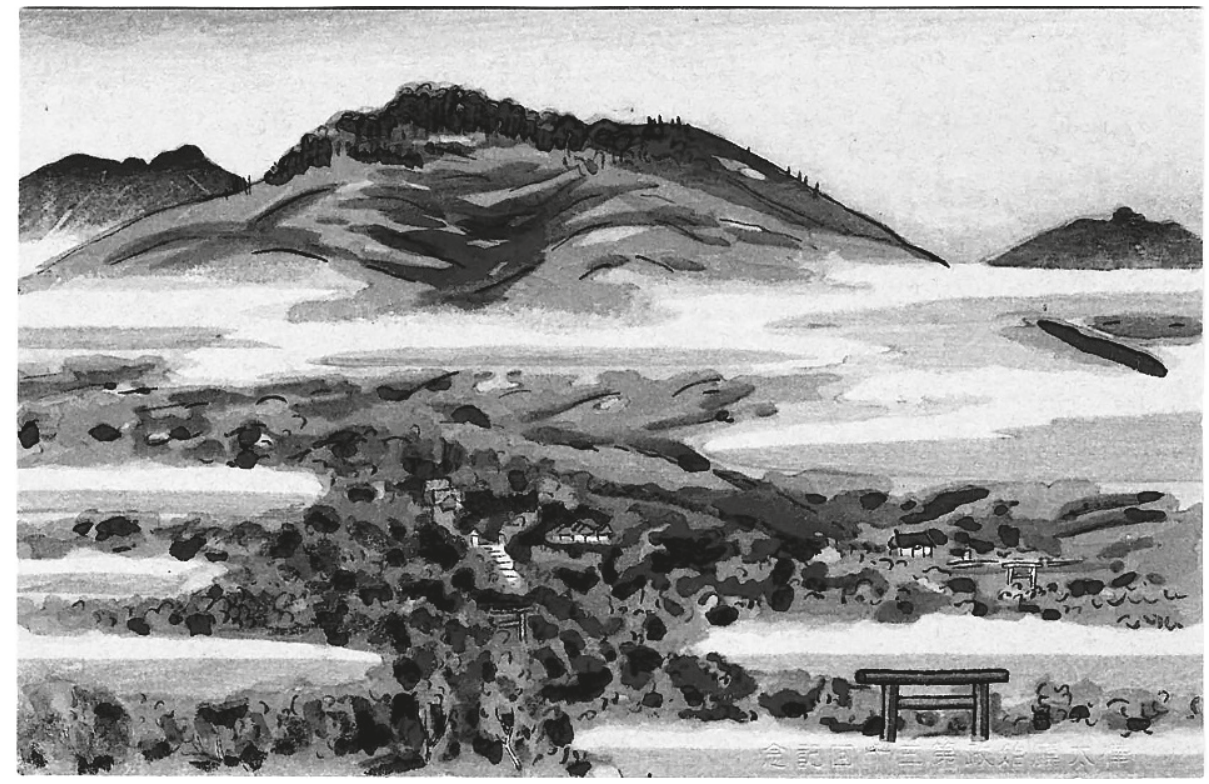

Fig. 1. Köjirō Funasaki. Commemorative Postcard for the $30^{\text {th }}$ anniversary of the inauguration of Karafuto Prefecture. 1936. Sapporo City Library, Sapporo

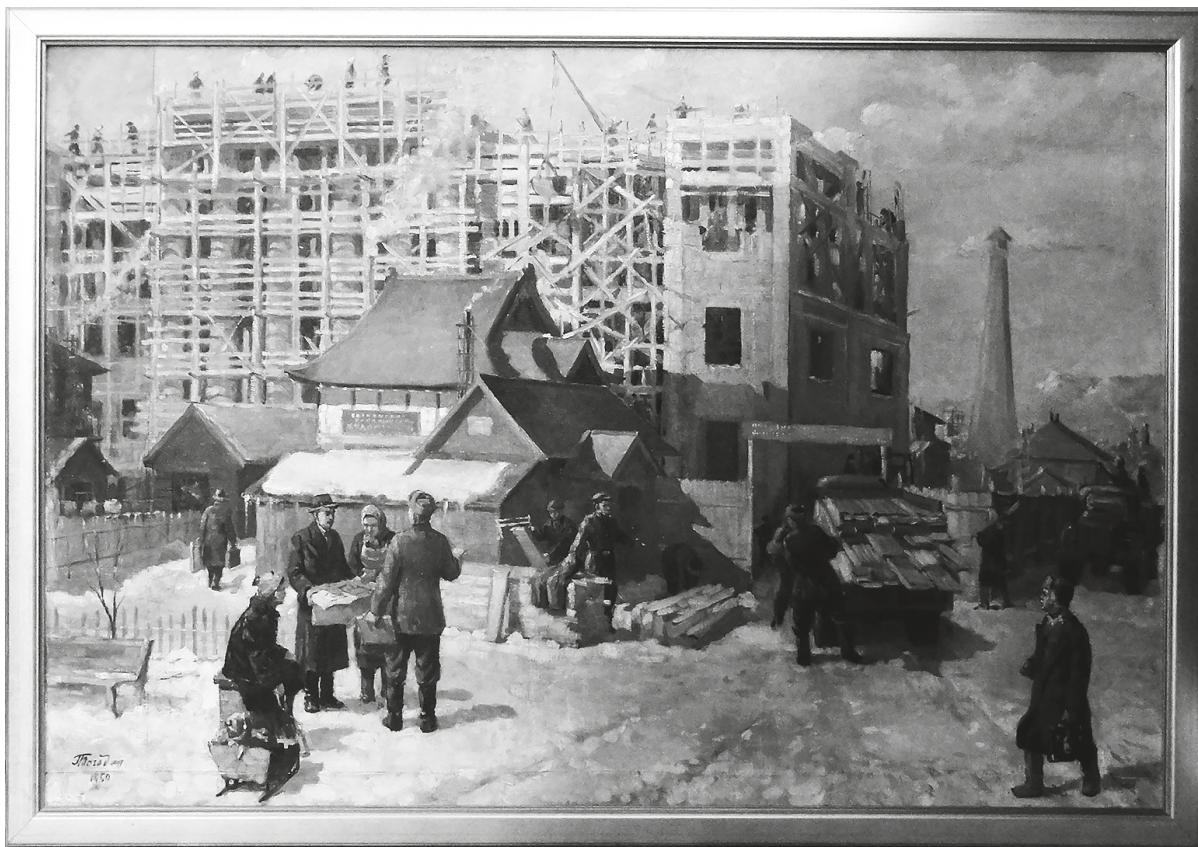

Fig. 2. Pavel Pogodin. Construction Site of Fishery Office. 1950. Sakhalin Regional Art Museum, Yuzhno-Sakhalinsk 
Yury Stepanov belongs to a new generation of artists that are native to Sakhalin, even though he was born in 1935 [4]. In fact, he was born several tens of kilometers inland from Alexandrovsk-Sakhalinsky, Anton Chekhov's town in Northern Sakhalin, and completed his secondary education on the island of Itrup. He studied art in Moscow and lived and worked in Yuzhno-Sakhalinsk from 1960. The magnificent Kuril Islands fascinated him and became his favorite subject of painting (Ill.58). He visited more islands than other Sakhalin artists who usually visited only Kunashir and Shikotan.

The importance of the Shikotan Group's activities should be stressed even in the context of Sakhalin Region, which administratively includes the Kuril Islands [9]. Though the Group was composed of artists from Moscow and Primorye, it played a key role in the formation of landscape painting. The artists assiduously frequented Shikotan Island from 1966 to 1991, and succeeded in epitomizing the southern part of the Kuril Islands as an integral part of Russia, and consequently Europe. They used stylized and typified landscapes of the Mediterranean and the Crimea, both traditional sites for Russian and European paintings, to represent this area with bays, seacoasts with cliffs and grand volcanos.

Many artists born in Sakhalin after the Soviet rule was established started their career in the 1970s and 1980s. Naturally, they could easily recognize their identity as being from Sakhalin. Natalia Kiryukhina (1955-), one of leading artists of Sakhalin, does not conceal her attachment to her Russianized homeland, sometimes resorting to Russian folklore and craft works [3, pp. 153-163]. Dyu Men Su (1948-) and Dyo Son En (1960-) are Korean-Russians, members of the Sakhalin's second largest ethnic group after Russians, but do not apparently stick to their Korean origins and instead work with modern painting techniques [5; 6]. Dyu Men Su transforms islands of the Kuril according to his visionary and expressionist poetics. On the other hand, Dyo Son En's recent work of Shikotan Island seems to trace the stereotyped format invented by the Shikotan Group (Fig. 3).

It is curious enough that so many artists have visited and depicted Shikotan and nearby islands. As a result, we often see the landscapes of this area not on site (it is too difficult to reach) but in other places such as Yuzhno-Sakhalinsk and Vladivostok. These landscapes in pictorial form are assimilable to the generic notions of Russian or European landscapes, and therefore the portrayed area may be recognized by the audience as a Russian territory or as a part of Europe.

Sergey Vasenkin, a recent entrant into the Russian Union of Artists, gives us a good example of assimilation. He was born in Orsk, along the Ural River dividing Europe and Asia, in 1963, and moved here and there from the Baikal-Amur Railway to the power plant construction site in Uzbekistan because of his engineer father. After military service, he moved to Sakhalin in 1984 and was soon fascinated by the sea of Okhotsk, working as welder for two months on Kunashir Island. Though most members of the Union of Artists in Sakhalin and Russian Far East studied at the art department of the former Khabarovsk teaching university or the Art Academy of Vladivostok, Vasenkin is self-taught and should be proud of his mastery skills and craftsmanship.

His main subject is seascapes, in which typical motifs of Sakhalin such as seals, sea lions, or Chekhov's portrait are occasionally inserted (Fig. 4). Most of his works focus only on rolling waves that wash against the shore (Ill.57). He learned the depiction of transparent seawater and 


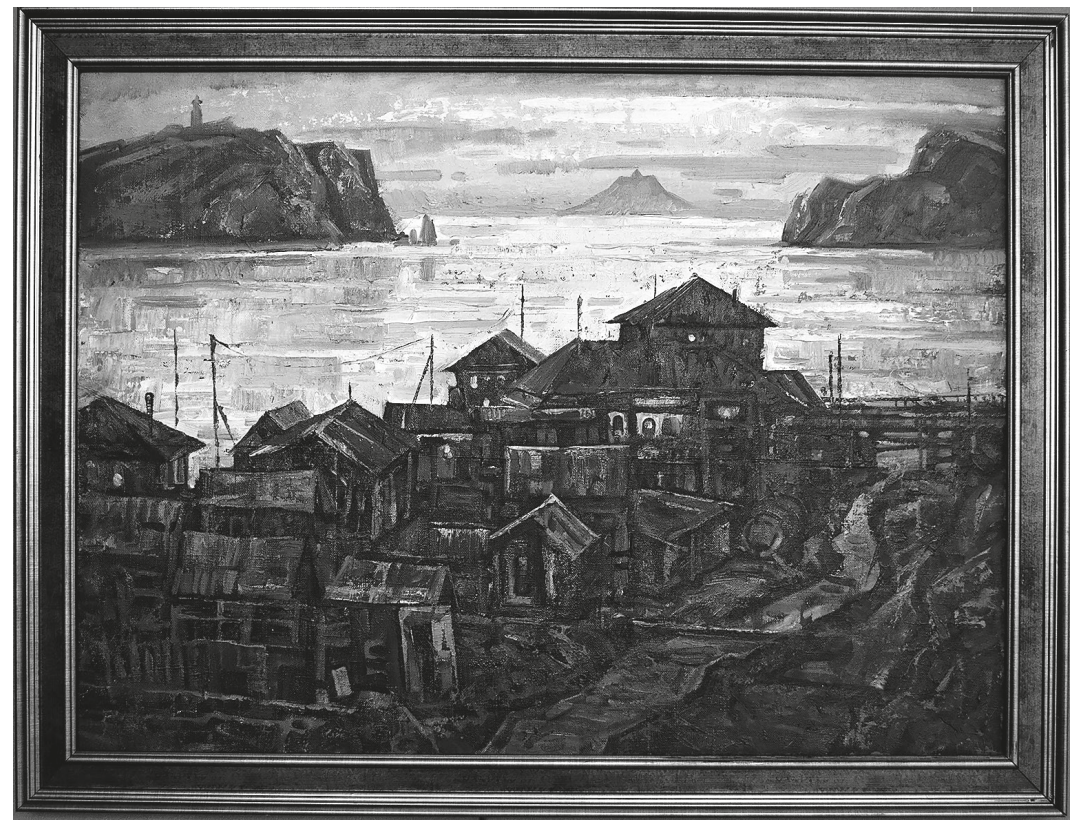

Fig. 3. Dyo Son En. Malokuril'sk. 2015. Private Collection

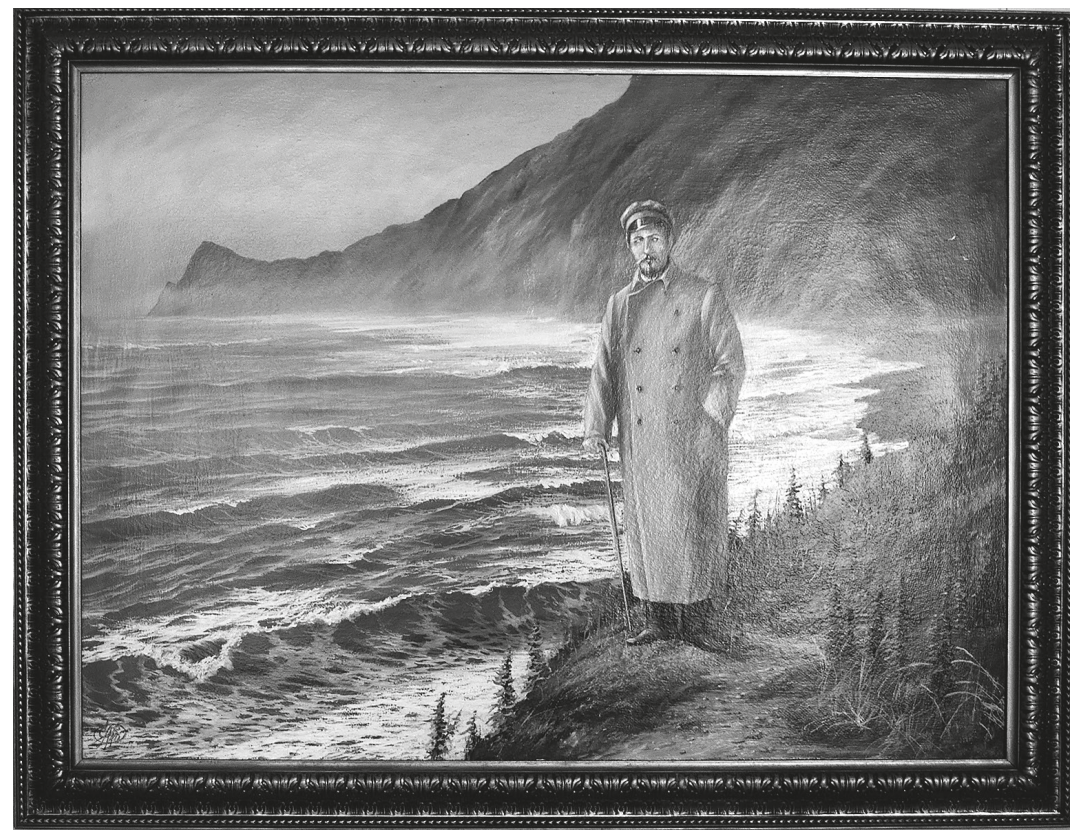

Fig. 4. Sergey Vasenkin. Landscape with Anton Chekhov. 2015. Private Collection 
the dramatic effect of light from Ivan Aivazovskii, one of the national painters of $19^{\text {th }}$ century Russia. Vasenkin skillfully uses palette knives and finishes his work in only several hours.

Aivazovskii was born and lived in Feodosiya, Crimea, and heroically represented the Black Sea. Thanks to his achievements, the Crimea became one of Russia's typical landscapes. Furthermore, since the Black Sea is a part of the Mediterranean, it could rightfully claim to be represented as such by Aivazovskii. Thus, the Black Sea became another window to Europe for Russia and the Crimean-like landscapes assumed functions as European landscapes. If it is so, then Vasenkin's works may have a similar role. Sakhalin comes to resemble the typically Russian Crimea and, consequently, Mediterranean Europe through his landscape paintings. A circuit of Sakhalin - Crimea/Russia - Mediterranean/Europe and vice versa constitutes a process of relating different places and assimilating territories through landscape or the representation of territories. Vasenkin does not consider his production a form of self-expression, nor does he cherish his works as if they were his own children. It can be said that an excellent craftsman like him whose works sell well could transform Sakhalin's landscape into something more similar to Russia and Europe at a collective, perceptional level of the viewers at least.

\section{References}

1. Bown M. C. Dictionary of Twentieth Century Russian and Soviet Painters. London, Izomar Publ., 1998. 388 p.

2. Brzhezovskaya N. A. Givi Mantkava. Zhivopis'. Grafika v kollektsii Sakhalinskogo oblastnogo khdozhestvennogo muzeia (Givi Mantkava. Painting. Graphic Art in the Collection of Sakhalin Regional Museum of Art). Vladivostok, Zolotoi Rog Publ., 2005. 200 p. (in Russian).

3. Brzhezovskaya N.A.; Du Men Su. Sakhalinskoe izobrazitel'noe iskusstvo v sobranii SGOKhM. Katalog kollektsii (Fine Art of Sakhalin in the Collection of the Sakhalin Art Museum. Catalogue of Collection). Khabarovsk, Platina Publ., 2008. 336 p. (in Russian).

4. Sakhalin Regional Museum of Art; Ministry of Culture of Sakhalin Region (eds.). Zasluzhennyi khdozhnik Rossii Yury Stepanov (Honored Artist of Russia Yury Stepanov). Yuzhno-Sakhalinsk, Sakhalinskaia oblastnaia tipografiia Publ., 2015. 136 p. (in Russian).

5. Sakhalin Regional Museum of Art (ed.). Dyo Son En. Iskusstvo. Tvorchestvo. Prostranstvo (Dyo Son En. Art. Creation. Space). Yuzhno-Sakhalinsk, Eikon Publ., 2014. 88 p. (in Russian).

6. Sakhalin Regional Museum of Art (ed.). Dyu Men Su (Dyu Men Su). Yuzhno-Sakhalinsk, Lukomor'e Publ., 2009. 96 p. (in Russian).

7. Teten'kina T. G.; Kustovoi V.N. (eds.). Izobrazitel'noe iskusstvo dal'nevostochnykh khdozhnikov $v$ cobranii Sakhalinskogo oblastnogo khdozhestvennogo muzeia. Katalog kollektsii (Fine Art of Far Eastern Artists in the Collection of Sakhalin Regional Museum of Art. Catalogue of Collection). Kaliningrad, Aksios Publ., 2013. 408 p. (in Russian).

8. Troegubova N.V.; Dyo Son En; Metel'skii Iu.N. (eds.). Sakhalinskoe regional'noe otdelenie Coiuza khdozhnikov Rossii - 25-letie so dnia sozdaniia (Sakhalin Regional Branch of the Russian Union of Artists $25^{\text {th }}$ Anniversary of the Foundation). Vladivostok, Dal'press Publ., 2014. 204 p. (in Russian).

9. Yakou H. The "Shikotan Group" and Two Tendencies of the Soviet Landscape Painting. Actual Problems of Theory and History of Art: Collection of articles, vol. 6. A. V.Zakharova; S. V. Maltseva; E. Yu. StanyukovichDenisova (eds.). Saint Petersburg, NP-Print Publ., 2016, pp.685-689. Available at: http://dx.doi. org/10.18688/aa166-9-74 (accessed 20 February 2017).

Title. The Formation of Landscapes in the Sakhalin and Kuril Islands.

Author. Hisashi Yakou - M. A., professor. Hokkaido University, Kita 10 Nishi 7, Kita-ku, Sapporo, 0600810 Japan.yakou@let.hokudai.ac.jp

Abstract. Sakhalin is one of the most remote areas from the art centers of Russia such as Moscow and St. Petersburg. As such, it has not been an object of close study in regard to the history of art and landscape painting. Except for the northern part of Sakhalin Island, this region was ruled by Japan until the end of World 
War II, and thus the art history of Sakhalin in a Russian context began only around that time. At first, Sakhalin was represented with a romantic and exotic vision by new settler artists who arrived from different parts of the USSR. As time passed, the artists, some of whom had been born in Sakhalin, tended to face the reality of the region, keeping step with the stylistic changes in Soviet realist paintings, and they produced works with numerous local motifs, such as the ocean, frozen sea, coastlines, islands, volcanoes, fish, seagulls, and sea lions, as well as art featuring the lives of northern indigenous people. At the same time, the crucial role played by the "Shikotan Group" should be stressed if we consider the importance of its activities in the development of typical landscapes of the Kuril Islands. In this paper the focus will be on the analysis of the works by local artists who have been active since the demise of the Soviet Union. Natalia Kiryukhina, a leading artist of Sakhalin, does not conceal her attachment to her homeland, epitomizing its landscapes and sometimes resorting to Russian folklore and artistic crafts. Sergey Vasenkin adores and assiduously learns from Ivan Aivazovsky and seems to transform the individual scenery of Sakhalin into one of ideal, collective Russian landscapes. Looking closely at the works of these artists and others, we can argue that, through the process of representing a place such as Sakhalin, which was the land of indigenous people where the settlers were displaced one by the other, the landscape of the place transfigures itself according to the gaze of viewers and aspires to be an integral part of a broader national structure while retaining its local features.

Keywords: Sakhalin; Kuril Islands; Shikotan Group; landscape painting; Soviet Impressionism; Mediterranean; Crimea; Far East.

Название статьи. Формирование традиции пейзажной живописи Сахалина и Курильских островов.

Сведения об авторе. Якоу Хисаши - М.А., профессор. Университет Хоккайдо. Кита 10 Ниши 7, Кита-ку, Саппоро, Япония, 060-0810. yakou@let.hokudai.ac.jp

Аннотация. Сахалин - один из самых отдаленных районов от таких художественных центров России, как Москва и Санкт-Петербург. В связи с этим, он еще не стал объектом пристального изучения в отношении истории искусства и развития пейзажной живописи. За исключением северной части острова Сахалин, этот регион находился под властью Японии до конца Второй Мировой Войны, и, следовательно, развитие искусства Сахалина в российских условиях началось только примерно в это время. В начале Сахалин был представлен романтическим и экзотическим видением молодых художников поселенцев, приехавших из разных уголков СССР. Прошло время, художники, некоторые из которых родились уже на Сахалине, как правило, обратились к изображению местных реалий, в русле стилистических измененийв советской реалистической живописи, и начали создавать произведения с многочисленными местными мотивами, такими как океан, замершее море, побережье, острова, вулканы, рыба, чайки и морские львы, а также отражать жизнь коренного населения Севера. В то же время, следует подчеркнуть ключевую роль «шикотанской группы» в развитии типических пейзажных мотивов Курильских островов. В данной работе основное внимание будет уделено анализу произведений местных художников, активно работающих с момента распада Советского Союза. Наталья Кирюхина, ведущий художник Сахалина, не скрывает своей привязанности к своей родине, воплощая свои пейзажи и иногда прибегая к помощи русского фольклора и художественных ремесел. Сергей Васенкин любит и усердно изучает творчество И. Айвазовского и стремится сделать неповторимые пейзажи Сахалина частью идеального собирательного образа русского пейзажа. Внимательно проанализировав работы этих художников, можно утверждать, что в процессе представления такого места как Сахалин, которое являлось землей коренных народов, и где поселенцы сменяли друг друга, пейзаж преображается в соответствии с взглядом зрителя и стремится быть неотъемлемой частью более широкой национальной структуры, сохраняя при этом свои местные особенности

Ключевые слова: Сахалин; Курилы; шикотанская группа; пейзажная живопись; советский импрессионизм; Средиземноморье; Крым; Дальний Восток. 


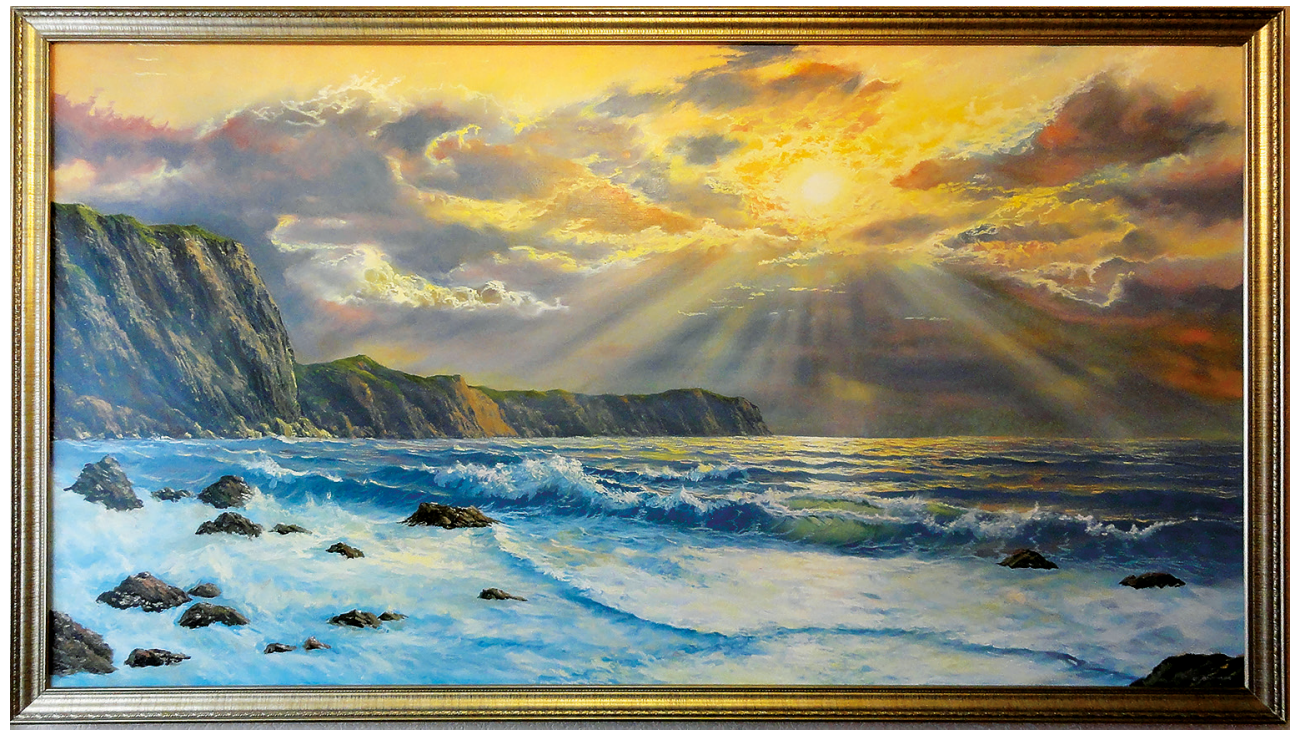

Ill. 57. Sergey Vasenkin. Landscape. 2013. Private Collection

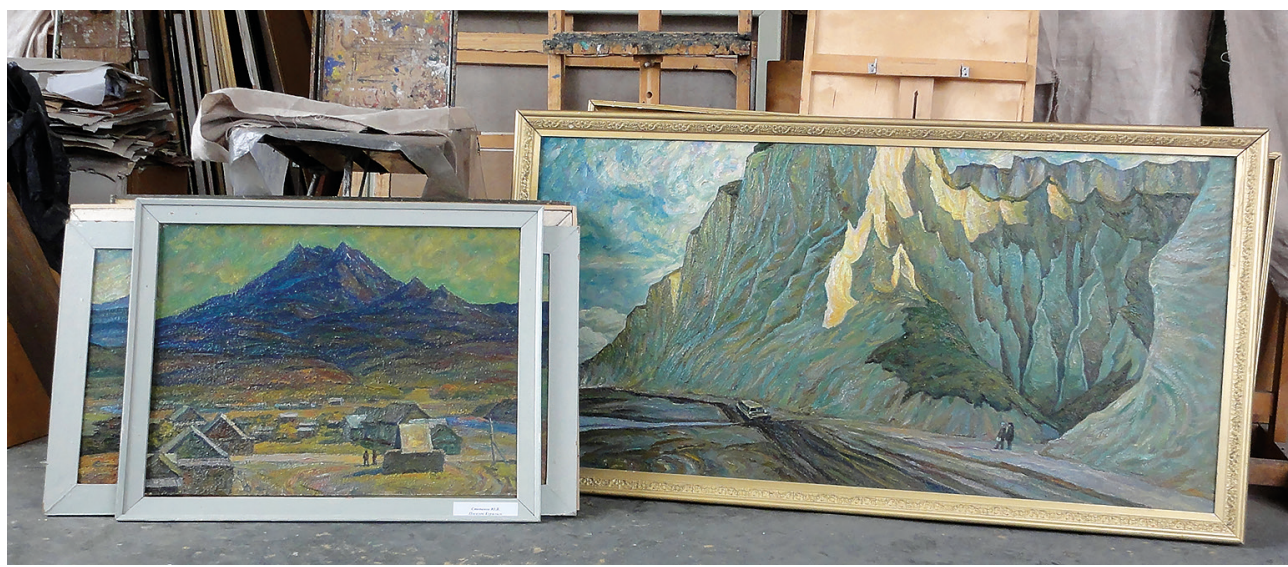

Ill. 58. Yury Stepanov's Studio in Yuzhno-Sakhalinsk 